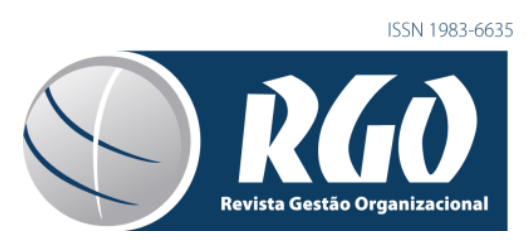

\title{
INTERNATIONAL HUMAN RESOURCE MANAGEMENT FOR EXPATRIATION IN EARLY AND LATE MOVER MULTINATIONALS
}

\author{
GESTÃO INTERNACIONAL DE RECURSOS HUMANOS PARA EXPATRIAÇÃO EM \\ MULTINACIONAIS EARLYE LATE MOVERS \\ ALESSANDRA COSTENARO MACIEL \\ Doutora em Administração pela USCS \\ Professora da IMED Business School \\ Orcid: http://orcid.org/0000-0002-9391-1799 \\ E-mail: alessandra.maciel@imed.edu.br \\ Endereço: Rua Senador Pinheiro, 304, Vila Rodrigues - CEP 99.070-220- Passo Fundo - RS \\ GIANA DE VARGAS MORES \\ Doutora em Agronegócios pela UFRGS \\ Professora do Programa de Pós-graduação em Administração da IMED Business School \\ Oricd: http://orcid.org/0000-0003-3733-2220 \\ E-mail: gimores@gmail.com \\ EDUARDO DE CAMARGO OLIVA \\ Doutor em Administração pela USP \\ Professor do Programa de Pós-graduação em Administração da USCS \\ Orcid: http://orcid.org/0000-0002-7454-3759 \\ E-mail: eduardo.oliva@uscs.edu.br \\ EDSON KEYSO DE MIRANDA KUBO \\ Doutor em Administração de Empresas pela FGV-SP \\ Professor do Programa de Pós-graduação em Administração da USCS \\ Orcid: http://orcid.org/0000-0001-9017-2487 \\ E-mail: edson.kubo@prof.uscs.edu.br
}

\begin{abstract}
The rise of multinational corporations in emerging economies led to an interest in understanding human resource management in multinationals with subsidiaries. Our research aims to analyze the international human resource management practices used for the expatriation of professionals in early and late mover multinationals located in Brazil. This research has a qualitative approach with multiple case studies, and it is both exploratory and descriptive. We perform interviews, document analyses, and observation. The results show similarities between both analyzed groups, except in the recruitment and selection, career development, and work relations practices. We conclude that both in the early and late mover multinationals there are no repatriation programs focused on career development, and specific process to assess the expatriates' performance.
\end{abstract}

Keywords: International human resource management. Expatriation practices. Early mover multinationals. Late mover multinationals.

Data de submissão: 13/11/2019. Data de aceite: 04/12/2019. Data de publicação: 17/12/2019.

Artigo selecionado no fast track do COGECONT - International Conference in Management and Accounting, realizado na Universidade Comunitária da Região de Chapecó - Unochapecó, Chapecó - SC, de 17 a 19/10/2019. 


\section{EDIÇÃO ESPECIAL: COMEMORATIVA AOS 45 ANOS DOS CURSOS DE GRADUAÇÃO EM \\ CIÊNCIAS CONTÁBEIS E ADMINISTRAÇÃO DA UNOCHAPECÓ}

\section{RESUMO}

O aumento de multinacionais em economias emergentes levou a um interesse em compreender a gestão de recursos humanos em multinacionais com suas subsidiárias. $\mathrm{O}$ artigo tem como objetivo analisar as práticas de gestão internacional de recursos humanos utilizadas para a expatriação de profissionais em multinacionais early e late movers localizadas no Brasil. Esta pesquisa possui uma abordagem qualitativa, exploratória e descritiva. Para tanto, foram realizadas entrevistas, análises de documentos e observação em quatro multinacionais. Os resultados mostram semelhanças entre os dois grupos analisados, exceto nas práticas de recrutamento e seleção, desenvolvimento de carreira e relações de trabalho. Evidencia-se que, tanto nas multinacionais early quanto nas late movers estudadas, não há programas de repatriação focados no desenvolvimento de carreira e processo específico para avaliar o desempenho dos expatriados.

Palavras-chave: Gestão internacional de recursos humanos. Práticas de expatriação. Multinacionais ealy movers. Multinacionais late movers.

\section{INTRODUCTION}

Human resource management is a key competitive advantage for national and foreign organizations, regardless of whether they are located in traditional or emerging markets. However, the increase in international operations leads to a specialization in the global labor market, bringing new challenges related to International Human Resource Management (IHRM) in the organizations. These challenges encompass expatriation practices, as well as matters related to the expatriates' adaptation to the new cultural context, multicultural work environments, and challenges related to their adjustment to the host country's culture (KUBO; BRAGA, 2013).

With regards to the companies' internationalization, the early and late mover categories also fulfill the role of providing an understanding of the situation in developed and emerging countries (BARTLETT; GHOSHAL, 2000; DJODAT; KNYPHAUSEN-AUFSE $\beta$, 2017). Historically, developed countries create the first competitors in a certain industrial sector, called early movers. The competitors that arrived after the establishment of the market, the late movers, are usually from emerging countries (BARTLETT; GHOSHAL, 2000; ROCHA; BORINI, 2011).

The companies that settle in a foreign market first (early movers) have technological leadership advantages, resource preemption, and consumer cost development benefits for supplier exchanges (LIEBERMAN; MONTGOMERY, 1988). However, a study performed on four automobile multinationals located in Brazil (two early movers and two late movers) shows that the late mover subsidiaries, located in a host country, learn from the early movers' experiences and build skills to develop products more quickly (AMATUCCI, 2010).

The expansion and conduction of their international business through subsidiaries requires international transfers of head office employees to work in the subsidiaries; these employees are called expatriates (REGO; CUNHA, 2009; LIMA, BRAGA, 2010; DOWNING et al., 2013; ZWIELEWSKI; TOLDO, 2015). It is the responsibility of the IHRM to provide support through expatriation program practices, helping with the expatriates' adaptation and retention (BIANCHI, 2015; ORSI et al., 2015). 


\section{EDIÇÃO ESPECIAL: COMEMORATIVA AOS 45 ANOS DOS CURSOS DE GRADUAÇÃO EM CIÊNCIAS CONTÁBEIS E ADMINISTRAÇÃO DA UNOCHAPECÓ}

The role of the IHRM is to manage the international transfer process (ORSI et al., 2015), structuring the main steps that will be taken in expatriation. Such steps are broken down into recruitment and selection, training and development, compensation, career, performance assessment (REGO; CUNHA, 2009; CHO et al., 2013; DOWLING et al., 2013; YAHIAOUI, 2014; SHI; FRANKLIN, 2014), encompassing work relations, found in studies by Orsi et al. (2015).

Although late mover multinationals have gained more attention in the last decade (BONACHE; FERNANDEZ, 1997; AMATUCCI, 2010; FLEURY; FLEURY, 2012; CHO et al., 2013; CUERVO-CAZURRA; RAMAMURTI, 2013; YAHIOUI, 2014; KOTABE; KOTHARI, 2016), we would like to stress the lack of research to analyze the IHRM practices in multinationals from emerging countries, such as the BRICS countries (Brazil, Russia, India, China, and South Africa) (ADAMS et al., 2016; BUDHWARA et al., 2017), comparing them to the early mover multinationals (which come especially from Europe and the United States). Besides, the IHRM is seen as a key area to provide a competitive advantage to multinationals.

Our research aims to analyze the IHRM practices used for the expatriation of professionals in early and late mover multinationals located in Brazil. We seek to contribute to the theoretical gap in research, that examines the phenomenon of expatriation in Brazilian multinationals, since most of the publications about it come from traditional markets. It can also support expert consultancies on people mobility and provide IHRM analysis for chemical industry organizations.

\section{THEORETICAL BACKGROUND}

The six practices contemplated in the expatriation programs include recruitment and selection, training and development, compensation, career, performance assessment, and work relations. Although the recruitment of expatriates is performed internally (YAHIAOUI, 2014), usually, the board of directors is responsible for choosing the expatriate (ORSI et al., 2015). However, in order to choose the right person and increase the chances of having a successful expatriation, such criteria need to be observed: professional and international experience, gender, intercultural skills, behavioral skills and techniques, motivations, language fluency, family flexibility (MENDENHALL et al., 1987; DOWLING et al., 2004; REGO; CUNHA, 2009; CHO et al., 2013).

Studies focus on on-the-job learning, showing training strategies that are focused on internationalization as a learning experience, or using the subsidiaries as a tool (ZHANG; FAN, 2014), revealing the neglect towards training during repatriation (LIMA; BRAGA, 2010). In general, training practices before the mission encompass language education, cultural preparation, pre-mission experience, and during the mission, counseling, mentoring, coaching, participation in global meetings, and job rotation (TUNG, 1982; CALIGIURI; TARIQUE, 2006; REGO; CUNHA, 2009; CHO et al., 2013).

To encourage employees to accept to go on an international mission, multinationals consider ways to reward their expatriates, which involves negotiation, equivalence, location, global and regional plans, mobility awards, and benefit flexibility (WENTLAND, 2003; ORSI et al., 2015). However, based on the perception of Brazilian expatriates, the financial aspects do not compensate for the hassles of expatriation (VIANNA; SOUZA, 2009). For this reason, intangible factors need to be brought up in relation to learning opportunities and development for career progression upon repatriation (MENDENHALL et al., 1987; REYNOLDS, 1997; BONACHE; FERNANDEZ, 1997; CHO et al., 2013; SHEN; XHI, 2018).

Another matter that deserves attention is regarding the fact that the career is associated to the last stage of the expatriation process - repatriation -, since the employee's 
return can be considered a deviation in the career progression in their country of origin (HARVEY; NOVICEVIC, 2006). There are cases in which the career progression upon return does not meet their expectations, considering that many expatriates do not get acknowledged by the organization for the knowledge and skills they acquired during expatriation (SUUTARI; BREWSTER, 2003).

The organizational performance management involves a cycle, which involves setting the expectations between the manager and the expatriate, monitoring, and assessing the performance (ORSI et al., 2015), in which the latter is one of the criteria to assess the success of the expatriation (SHI; FRANKLIN, 2014). Therefore, the decisions in terms of promotion, compensation, development, succession and termination plans need to be subsidized (REGO; CUNHA, 2009; ORSI et al., 2015).

Another challenge for the IHRM of multinationals is meeting work relations to manage people differently according to the characteristics of each country. In this context, the multinational can adopt international work contract formalization modalities, such as suspension, division, maintenance, or termination of the contract (ORSI et al., 2015). The affirmative actions are an important factor, since they aim to mend work relations focused on groups that are discriminated and victimized by social exclusion and are thought of according to the political, economic, and social environment.

With regards to multinationals from emerging countries, such as the BRICS, because they are more recent, they can be considered immature, and even replicate the internationalization moves from the developed countries (BARTLETT; GHOSHAL, 2000; ROCHA; BORINI, 2011; BORINI et al., 2007; BUDHWARA et al., 2017). On the other hand, the internationalization of multinationals from developed markets, such as the United States, Japan, and Europe, is considered to be older and more mature, since they were the first competitors to enter a certain sector (BARTLETT; GHOSHAL, 2000; BORINI et al., 2007; ROCHA; BORINI, 2011).

In this context, the late mover multinationals, historically seen as the exporters, are taking over growing participation in the global production, operating factories in foreign countries. However, they go through their internationalization process under different conditions than those faced by the early movers (TANURE et al., 2007). For example, after the economic liberalization (late 80's and early 90's), Brazilian companies started to become internationalized. As a result, only the most resilient companies were able to prosper in a challenging environment, such as Gerdau, Weg, Embraer, Braskem, AmBev, Marcopolo, Petrobrás, JBS, Votorantim (FLEURY; FLEURY, 2012).

When analyzing Brazilian multinationals, the late movers located in Brazil, Australia, India, and Philippines, usually enter and remain in the global marketing, competing with low prices (BARTLETT; GHOSHAL, 2000). Another study performed with the main Brazilian multinationals showed that the decision to become international is related to internal factors, because of the establishment of their own commercial offices or subsidiaries abroad, and because of external factors, motivated by tax matters, risk diversification, and financial sustainability (TANURE et al., 2007). On the other hand, studies show that multinationals decide to get into developed markets aiming to explore the present, in terms of market share, infrastructure, and talent pool; and when they choose to enter developing markets, their intention is to explore potential opportunities (THITE et al., 2016). 


\section{METHOD}

This research is classified as exploratory and descriptive, with a qualitative focus, using data collected through field research. It is a multiple case study (YIN, 2010) performed on four multinationals located in Brazil. The field research was performed in a preliminary stage through the analysis of human resource policies and practices manuals, conduct and ethics codes, institutional sites, news media, and administrative documents.

Based on Bartlett and Ghoshal's (2000) definition, the four cases were divided into two groups (Table 1): early movers and late movers. To keep their anonymity, the names of the companies were replaced by letters: A (gas production company), B (chemical and polymer company), C (petrochemical company) and D (producer of surfactants and specialty chemicals). We justify the intentional selection of these multinationals because they have been internationalized for more than 10 years and have had structured expatriation processes for more than 10 years, which is the necessary amount of time to earn international expatriation designations.

Based on the theoretical reference regarding the IHRM practices, we developed two semi-structured interview scripts: one for the multinationals, represented by those responsible for the expatriation process, and another one for the expatriated professionals of each multinational. We performed pre-tests, the first script was applied to two human resource managers who are responsible for the international mobility of automobile multinationals, and the second script was applied to two Brazilian expatriates in missions in the United States (for 12 months) and Argentina (for 17 months). With that, we assessed the suitability of the questions and made adjustments in the scripts.

Twelve interviews were performed between September 2017 and February 2018, both in-person and online, according to the availability of the interviewees (Table 1). The average duration of each interview was 60 minutes. The transcript generated 96 pages for analysis. Through the snowball sampling technique, each multinational nominated expatriates to take part in the research. Because the data collection requires a specific audience, which is people who have been expatriated and those who are responsible for managing the expatriation process, the number of interviewees was considered low. The number of interviewees provided a satisfactory overview of the expatriation practices in the multinationals. We also justify it by using the saturation concept, which is when the search for new data would not add any information to the obtained material (MASON, 2010).

Table 1 - Data collection and profile of respondents

\begin{tabular}{|l|l|l|l|l|l|}
\hline Group & $\begin{array}{l}\text { Multina } \\
\text { tional }\end{array}$ & $\begin{array}{l}\text { Professional } \\
\text { position }\end{array}$ & \multicolumn{1}{|c|}{ Origin-destination } & \multicolumn{1}{|c|}{ Interviewee profile } & $\begin{array}{c}\text { Collection } \\
\text { technique }\end{array}$ \\
\hline $\begin{array}{l}\text { Early } \\
\text { movers }\end{array}$ & A & $\begin{array}{l}\text { Human } \\
\text { Resource } \\
\text { Director for } \\
\text { Americas }\end{array}$ & $\begin{array}{l}\text { Brazilian, expatriated } \\
\text { to Uruguay (five } \\
\text { years) and Argentina } \\
\text { (three years), and } \\
\text { repatriated }\end{array}$ & $\begin{array}{l}\text { I1 (Interviewee 1) } \\
\text { Age: } 51 \\
\text { First expatriated at 33 years, } \\
\text { after six years working in the } \\
\text { company }\end{array}$ & $\begin{array}{l}\text { Interview } \\
\text { ons } \\
\text { observation }\end{array}$ \\
\cline { 2 - 5 } & $\begin{array}{l}\text { General } \\
\text { Manager in } \\
\text { Paraguay }\end{array}$ & $\begin{array}{l}\text { Brazilian, expatriated } \\
\text { to Paraguay (on the } \\
\text { mission for two } \\
\text { years) }\end{array}$ & $\begin{array}{l}\text { I2 (Interviewee 2) } \\
\text { Age: 27 } \\
\text { Expatriated after five years } \\
\text { in the company at the age of } \\
25\end{array}$ & $\begin{array}{l}\text { Online } \\
\text { interview }\end{array}$ \\
\hline
\end{tabular}


EDIÇÃO ESPECIAL: COMEMORATIVA AOS 45 ANOS DOS CURSOS DE GRADUAÇÃO EM CIÊNCIAS CONTÁBEIS E ADMINISTRAÇÃO DA UNOCHAPECÓ

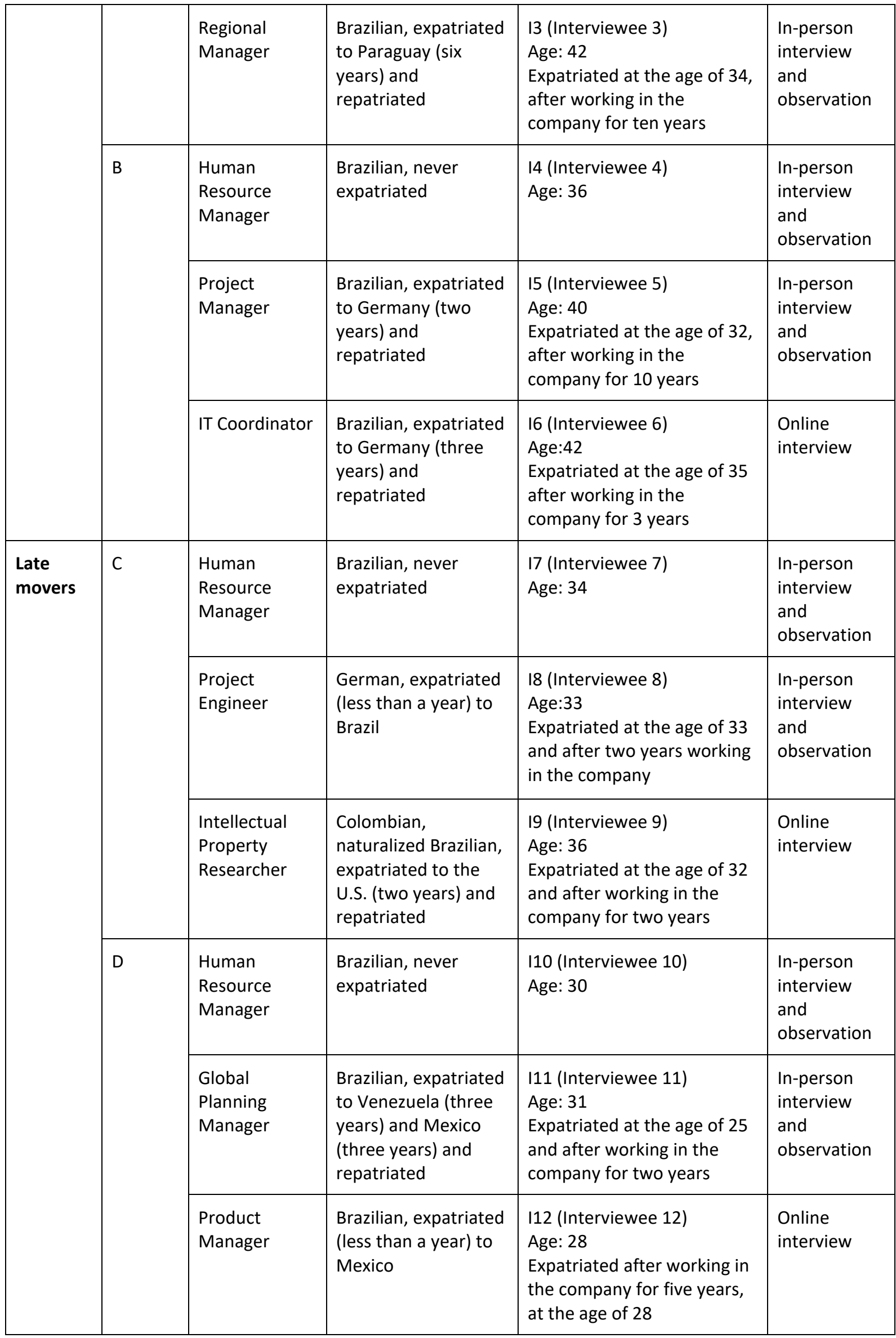

Source: Developed by the authors (2018). 
To better understand the phenomenon of the expatriation process, we used data triangulation, using interviews, documents, and observation. The material was submitted to content analysis, encompassing the stages proposed by Bardin (2009). This research contemplated six analysis categories: recruitment and selection; training and development; compensation; career; performance assessment; and work relations.

\section{RESULTS AND DISCUSSION}

The expatriation process approaches six practices identified in literature, which evidence found in both groups (early and late movers) are summarized in Table 2.

Table 2 - Expatriation practices in the analyzed multinationals

\begin{tabular}{|c|c|c|c|c|}
\hline \multirow[t]{2}{*}{ Practice } & \multicolumn{2}{|c|}{ Early mover multinationals } & \multicolumn{2}{|c|}{ Late mover multinationals } \\
\hline & A & B & $\mathrm{C}$ & D \\
\hline $\begin{array}{l}\text { Recruitment } \\
\text { and selection }\end{array}$ & $\begin{array}{l}\text { Expatriation } \\
\text { duration: three } \\
\text { years; } \\
\text { Defined profile } \\
\text { Internal } \\
\text { recruitment; } \\
\text { Selection } \\
\text { structured in } \\
\text { criteria }\end{array}$ & $\begin{array}{l}\text { Expatriation duration: } \\
\text { three years; } \\
\text { No defined profile; } \\
\text { Internal recruitment; } \\
\text { Selection: none }\end{array}$ & $\begin{array}{l}\text { Expatriation } \\
\text { duration: three } \\
\text { years; } \\
\text { No defined } \\
\text { profile; } \\
\text { Internal } \\
\text { recruitment; } \\
\text { Selection: none }\end{array}$ & $\begin{array}{l}\text { Expatriation } \\
\text { duration: three } \\
\text { years; } \\
\text { No defined profile; } \\
\text { Internal } \\
\text { recruitment; } \\
\text { Selection: none }\end{array}$ \\
\hline $\begin{array}{l}\text { Training and } \\
\text { development }\end{array}$ & $\begin{array}{l}\text { Cultural and } \\
\text { linguistic training; } \\
\text { Development: } \\
\text { mentoring }\end{array}$ & $\begin{array}{l}\text { Cultural and linguistic } \\
\text { training; } \\
\text { Development: job } \\
\text { rotation }\end{array}$ & $\begin{array}{l}\text { Cultural and } \\
\text { linguistic training; } \\
\text { Development: } \\
\text { coaching }\end{array}$ & $\begin{array}{l}\text { Cultural and } \\
\text { linguistic training; } \\
\text { Development: none }\end{array}$ \\
\hline Compensation & $\begin{array}{l}\text { Equivalence plan in } \\
\text { the country of } \\
\text { destination; } \\
\text { Bonuses for cost of } \\
\text { living; } \\
\text { Benefits package }\end{array}$ & $\begin{array}{l}\text { Equivalence plan in the } \\
\text { country of destination; } \\
\text { Bonuses for cost of } \\
\text { living; } \\
\text { Benefits package }\end{array}$ & $\begin{array}{l}\text { Equivalence plan } \\
\text { in the country of } \\
\text { destination; } \\
\text { Bonuses for cost } \\
\text { of living; } \\
\text { Benefits package }\end{array}$ & $\begin{array}{l}\text { Equivalence plan in } \\
\text { the country of } \\
\text { destination; } \\
\text { Bonuses for cost of } \\
\text { living; } \\
\text { Benefits package }\end{array}$ \\
\hline Career & $\begin{array}{l}\text { Repatriation: no } \\
\text { formal agreement; } \\
\text { Pre-expatriation } \\
\text { stage (interviews); } \\
\text { Repatriation with } \\
\text { no career } \\
\text { progression }\end{array}$ & $\begin{array}{l}\text { Repatriation: no formal } \\
\text { agreement; } \\
\text { Pre-expatriation stage } \\
\text { (interviews); } \\
\text { Repatriation with } \\
\text { career progression } \\
\text { and/or one-year career } \\
\text { stability }\end{array}$ & $\begin{array}{l}\text { Repatriation: no } \\
\text { formal } \\
\text { agreement; } \\
\text { Repatriation with } \\
\text { no career } \\
\text { progression }\end{array}$ & $\begin{array}{l}\text { Repatriation: no } \\
\text { formal agreement; } \\
\text { Repatriation with no } \\
\text { career progression }\end{array}$ \\
\hline $\begin{array}{l}\text { Performance } \\
\text { assessment }\end{array}$ & $\begin{array}{l}\text { Not specific for } \\
\text { expatriates }\end{array}$ & $\begin{array}{l}\text { Not specific for } \\
\text { expatriates }\end{array}$ & $\begin{array}{l}\text { Not specific for } \\
\text { expatriates }\end{array}$ & $\begin{array}{l}\text { Not specific for } \\
\text { expatriates }\end{array}$ \\
\hline Work relations & $\begin{array}{l}\text { Suspension and } \\
\text { maintenance of } \\
\text { contract; } \\
\text { Attention to } \\
\text { affirmative } \\
\text { questions: gender } \\
\text { and religion }\end{array}$ & $\begin{array}{l}\text { Suspension and } \\
\text { maintenance of } \\
\text { contract; } \\
\text { Attention to } \\
\text { affirmative questions: } \\
\text { discrimination }\end{array}$ & $\begin{array}{l}\text { Suspension and } \\
\text { maintenance of } \\
\text { contract; } \\
\text { There is no } \\
\text { attention to } \\
\text { affirmative } \\
\text { questions }\end{array}$ & $\begin{array}{l}\text { Suspension and } \\
\text { maintenance of } \\
\text { contract; } \\
\text { There is no } \\
\text { attention to } \\
\text { affirmative } \\
\text { questions }\end{array}$ \\
\hline
\end{tabular}

Source: Developed by the authors (2018).

We concluded that the four case studies have the autonomy to manage the operational structure of the subsidiaries around the world. Another similarity is the fact that 
the expatriation position is necessary, both for technical and management roles, if there are no local employees with the expertise requires for the job.

Although the selected early mover multinationals have a long history of international presence (more than 100 years), when compared to the late mover multinationals, with a short history of international presence (less than 20 years), there were no differences in the recruitment strategies of both groups. Both the company representatives and the expatriates reported that the expatriation position is internally disclosed, and the transfers have a set duration of three years, with the possibility of being prorogated from 12 to 36 months, as provided by the contract. However, the multinational $A$ has a recruitment technique that involves a previous mapping and identification, with the aid of a tool, of potential candidates to fill these vacancies.

There was a consensus among the interviewed human resource managers (multinationals B, C, and D) that the board of directors chooses the expatriate. In multinational $A$, the human resource department performs a pre-selection, in which the employee provides their mobility conditions. However, although there is not a selection process to choose the expatriate, we concluded, by interviewing the expatriates, that some criteria were followed such as professional experience, technical-behavioral knowledge, and interviews. Interviewee 1 , from multinational A, explained that the "Human resource management practice is to invite the candidates who fit the profile and have the characteristics required to fill the position to take part in the selection process". 12 stated: "I heard about the position from human resource, and they asked me to participate in the selection process".

The IHRM focuses on a more bureaucratic and less strategic performance, and for this reason, their practices provide short-term actions. There was a consensus both from the human resource managers and the interviewed expatriates that the concern with training practices revolves around the pre-departure stage, offering cultural and linguistic training, but there is no training upon repatriation. The analyzed multinationals use their subsidiaries as a training place to develop the expatriates and build their management and global resources. According to Interviewee 3, "Since my role was almost the same as in Brazil, there was no training, I learned on the job". In the cases of A, B, and C, there were development practices that involved mentoring, coaching, and job rotation programs, and formal meetings.

Through interviews with the human resource managers of the four multinationals, we concluded that the compensation practice is not standardized, and that it is flexible and negotiable for each expatriation. The practice is to use the equivalence plan based on the country of origin and, if there is a difference in the cost of living between the country of origin and country of destination, they add a percentage to cover it and the amounts are transposed to the country of destination with taxes and converted to the appropriate currency. 14 reported: "We also added the mobility premium, which consists of a hazard bonus for expatriates which country of destination has security matters such as Venezuela". Besides the fixed wage, there is a benefits package offered during expatriation and repatriation, included in the contract.

There was a consensus among the human resource managers on to the expatriate career management, in which the full cycle encompasses the mission and repatriation, with no formal agreement with regards to the jobs to be taken in repatriation or return and stability guarantees. However, when the expatriation period is nearing its end, these multinationals search for available positions, and analyze the company's situation, aiming to guarantee the return or a new expatriation with position equivalency. 17 explained: "We don't know the position or department that will be available in the future, so when we do not allocate them 
in one place, we place them in another company from the group that has a position available, and there is also the possibility of a permanent transfer for those who accept it".

This strategy is more detailed in multinational A, once it focuses on the professional's career perspective before the expatriation, through career interviews. On the other hand, multinational $B$ is better structured in the post-expatriation stage, offering career progression for the employees' repatriation or one-year stability in their jobs post-repatriation. This research identified that the multinationals usually provide the international experience at the beginning of the employee's career, and the average time in the company varies from three to five years, and the professionals' average age is 30 .

Although there is not an exclusive performance assessment practice for the expatriate's condition, the performance management system of the four researched cases contributes to the selection, training decisions, career development, and progression of the expatriate, because it ponders the employee's performance over the last three years working in the company. Despite the deficiencies detected in the expatriate's performance management, both the early and late movers set expectations, once all interviewed expatriates explained their goals and the expected results during their expatriations.

The performance assessment, with biannual or annual feedback, specifically for expatriates, is not formal and structured practices, although they can happen informally or upon the expatriate's request in the researched multinationals. Empirically, in case the expatriate, during repatriation it is offered a better role, it means the result of the expatriation was positive, as well as the feedback. 111 reported: "The sequence of facts tells me the feedback was positive, because I always returned to better career positions. But there was no feedback on the expatriation".

There was a consensus among the interviewed human resource managers that multinationals manage the international work contract, complying with the labor and tax laws of each country. In the four analyzed cases, the multinationals maintain the work contract in the country of origin, in order to collect the worker's rights, as provided by the Brazilian law. At the same time, the work contract in the country of origin is suspended, since there needs to be a new contract in the country of destination in order to comply with the local labor and tax laws. I1 stated that "When an expatriate comes from France to Brazil, they come with a contract that was made there, but later, I need to give them a contract and work permit from Brazil to comply with the local legislation, as it is done with local employees".

There were divergences as to the management of affirmative matters in the expatriation programs in both groups. Although the affirmative matters directly affect the efficacy of the expatriation programs, only early mover multinationals, through the IHRM, reported being cautious with regards to gender and discrimination, especially in countries such as the U.S., Singapore, and Germany, where these matters are latent. I1 reported: "I cannot send a resume with information such as gender, age, education. You cannot characterize the person. That is why we had to remove everything from the information system". On the other hand, late mover multinationals did not take such cautions, nor do they manage these matters, because they are not latent in the countries where they have subsidiaries. Both companies justified that they never had problems related to this.

The case studies provided a contextual description to understand the gaps in the expatriation process, especially regarding the performance management system which subsidizes decisions about the selection, training, career development and progression for internal mobility (both nationally and internationally) of the employees. Although this practice is based on the potential identification and skill assessment criteria (performed every three 
years), such evaluation is not always used to identify employee mobility, especially in the multinationals B, C, and D. This finding converges with Yahiaoui (2014), a research performed with two companies, in which one was the head office, located in France, and the other was the subsidiary, located in Tunisia. This is because the choice of the expatriate is often made by the board of directors, which corroborates with Orsi et al. (2015), when they mentioned such nomination as a deficiency in the selection process, reinforcing the urgency of expatriation, leading to a fragile structuration of the process.

The analysis of selection practices reveals the criteria that need to be met in order for a valid and effective selection of expatriates, both in the early and late mover multinationals, considers the following criteria: professional experience, international experience, gender (DOWLING et al., 2004), fluency in the foreign language (YAHIAOUI, 2014), and family flexibility and adjustment (MENDENHALL et al., 1987; CHO et al., 2013). Compared to studies, this research shows that behavioral skills are usually more important when choosing the expatriate than technical or language skills. This is the opposite of Yahiaoui's (2014) study, in which the recruitment of expatriated managers is based on technical skills and age, the latter being justified by the Tunisian culture, which focuses on respect for the elders.

Besides, these results reinforce current studies that state that training practices offered to expatriates are limited to actions taken before the mission, and focused essentially on cultural and linguistic preparation, converging with evidence shown by Tung (1982), Rego and Cunha (2009) and Cho et al. (2013). It also confirms the lack of cultural training for repatriation, which is also noted in Lima and Braga (2010), when they pointed out that companies invest in reactive and short-term training practices. This research also resembles the results of Zhang and Fan (2014), by emphasizing that expatriates were trained in their technical and behavioral skills during the mission, using the subsidiary and the internationalization as learning, although these were not contemplated in the IHRM practices in their places of origin.

Based on empirical data, this study provides a holistic view of the career management practices, which despite being informal and unstructured, have insights for pre-expatriation actions, through career interviews, and in the post-expatriation stage, through career progression for repatriation and job stability in the post-repatriation stage. The discussions about the career before and during expatriation corroborated the practices exposed by Suutuari and Brewster (2003). The research reinforces that the international experience is provided at the beginning of the professional's career, which follows Rego and Cunha (2009), but different from the findings of Yahiaoui (2014), by defending expatriation based on criteria such as age and experience in management roles.

The analysis of the work relation practices shows unanimity in the formalization of the work contract, aiming to comply with the labor and tax laws in Brazil and the country of destination. It reinforces the research developed by Orsi et al. (2015), studying reward policies for expatriated executives, and highlighting that the suspension and maintenance of the contract are the most popular contract formalization methods among Brazilian companies. However, with regards to the management of affirmative matters in the expatriation programs, this study shows that only early mover multinationals ( $A$ and $B$ ) have such practices, due to their experience in the global market and for having been exposed to situations that involve discrimination and diversity in the work environment.

We concluded that the compensation practice in multinationals is exclusively focused on financial rewards (BONACHE; FERNANDEZ, 1997; ORSI et al., 2015), before the employee accepts the mission, with no being periodically reviewed or adjusted to the subsidiary's reality. 
This finding resembles those of Yahioui (2014), verifying the adjustment of the rewards model in a subsidiary through variable compensation based on goals and productivity. Another point considers intangible rewards such as security and acknowledgment, both connected to repatriation, which corroborates with research with Brazilian multinationals that also do not include repatriation in the expatriation contracts (ORSI et al., 2015). This research found that equity and non-monetary rewards are factors that influence the expatriation satisfaction perception, and not distributive justice (SHEN; XHI, 2018).

\section{FINAL CONSIDERATIONS}

This research showed there are no significant differences in the expatriation practices among early and late mover multinationals. In both groups, similarities were found in the way the training, compensation, career, performance assessment, and work relations practices were structured. The differences were focused on recruitment and selection practices, as well as career development and work relations.

The fragilities found in the late mover multinationals were also found in the early movers, with regards to career development and performance assessment practices. These findings show that the time of exposure to the international market, being older and mature (early movers), and favorable political and economic conditions for internationalization, do not ensure advantages when it comes to structuring the IHRM practices for expatriation in the early mover multinationals.

Theoretically, our research contributes a methodological perspective with double focus, that is, the organization and the expatriate. It should be noted the lack of studies about the IHRM practices in Latin America and in the BRICS countries. It also identifies trends with regards to work mobility, as well as an increase in definitive transfers and short-term missions, which last from three months to one year, for the implementation of projects. These reduce costs regarding bonuses and benefits for expatriates.

In terms of empirical contribution, this research provides subsides for late mover multinationals, as early movers have more refined and better-structured practices in the following aspects. With reference to recruitment and selection practices, they have a predefined profile for the expatriate, as well as structured criteria for the selection. In career practice, they perform interviews in the pre-expatriation stage to identify the employee's mobility, and post-expatriation to guarantee the expatriation and job stability. In the work relations practice, they pay attention to affirmative matters that concern diversity in the organizational environment.

We suggest continuing this research agenda to investigate IHRM and practices in multinationals in the BRICS countries. Another suggestion is to verify if the IHRM in multinationals of these countries choose different approaches when operating in different countries, analyzing similarities and differences in their countries of origin and subsidiaries abroad.

\section{REFERENCES}

ADAMS, K.; NYUUR, T. B.; ELLIS, F. Y. A.; DEBRAH, Y. A. South African MNCs' HRM systems and practices at the subsidiary level: insights from subsidiaries in Ghana. Journal of

International Management, New York, v. 23, n. 2, p. 180-193, 2017. DOI:

10.1016/j.intman.2016.07.001. 
AMATUCCI, M. Diferenças entre first movers e late movers na capacitação para o desenvolvimento de produtos na indústria automobilística. Revista de Administração e Inovação, São Paulo, v. 7, n. 4, p. 66-86, 2010. DOI: 10.5585/RAI.2010552.

BARDIN, L. Análise de conteúdo. Lisboa: Edições 70, 2009.

BARTLETT, C. A.; GHOSHAL, S. Going global: lessons from late movers. Harvard Business Review, Boston, v. 78, n. 2, p. 132-142, 2000. Disponível em: https://hbr.org/2000/03/goingglobal-lessons-from-late-movers. Acesso em: 10 jan. 2019.

BIANCHI, E. M. P. G. Repatriation: reflections on organizational practices and individual implications around the globe. Gestão \& Regionalidade, São Caetano do Sul, v. 31, n. 93, p. 144-160, 2015. DOI: 10.13037/gr.vol31n93.3353.

BONACHE, J.; FERNANDEZ, Z. Expatriate compensation and its link to the subsidiary strategic role: a theoretical analysis. The International Journal of Human Resource Management, London, v. 8, n. 4, p. 457-475, 1997. DOI: 10.1080/095851997341559.

BORINI, F. M.; URBAN, T. P.; FLEURY, M. T. L.; ROSAS, A. R. First movers x late movers: estudo de casos da indústria de cimentos. In: FLEURY, A.; FLEURY, M. T. L. (Orgs.).

Internacionalização e os países emergentes. São Paulo: Atlas, 2007.

BUDHWARA, P.; TUNG, R. L.; VARMAC, A.; DOD. H. Developments in human resource management in MNCs from BRICS nations: a review and future research agenda. Journal of International Management, New York, v. 23, n. 2, p. 111-123, 2017. DOI:

10.1016/j.intman.2017.04.003.

CALIGIURI, P.; TARIQUE, I. 6). International assignee selection and cross-cultural training and development. In: Stahl, G. K., Bjorkman, I. (Eds.). Handbook of Research in International Human Resource Management. Northampton: Edward Elgar Publishing, 2006. p. 302-322.

CHO, T.; HUTCHINGS, K.; MARCHANT, T. Key factors influencing Korean expatriates 'and spouses' perceptions of expatriation and repatriation. The International Journal of Human Resource Management, London, v. 24, n. 5, p. 1051-1075, 2013. DOI: 10.1080/09585192.2012.725079.

CUERVO-CAZURRA, A.; RAMAMURTI, R. Introduction. In: CUERVO-CAZURRA, A.; RAMAMURTI, R. (Eds.). Understanding multinationals from emerging markets. Cambridge: Cambridge University Press, 2013. p. 01-11.

DJODAT, N.; KNYPHAUSEN-AUFSE $\beta$, D. Revisiting Ghoshal and Bartlett's theory of the multinational corporation as an interorganizational network. Management International Review, Wiesbaden, v. 57, n. 3, p. 349-378, 2017. DOI: 10.1007/s11575-016-0298-3.

DOWLING, P. J.; FESTING, M.; ENGLE, A. D. International human resource management. Cengage Learning EMEA: 2013. 
DOWLING, P.; WELCH, D.; SCHULER, R. International human resource management: managing people in a multinational context. Cincinnati: South-Western College Publishing, 2004.

FLEURY, A.; FLEURY, M.T.L. Multinacionais brasileiras: competências para a internacionalização. São Paulo: FGV Editora, 2012.

HARVEY, M.; NOVICEVIC, M. M. The evolution from repatriation of managers in MNEs to 'patriation' in global organizations. In: STAHL, G. K.; BJÖRKMAN, I.; MORRIS, S. (Eds.).

Handbook of research in international human resource management. Massachusetts: Edward Elgar Publishing, 2006.

KOTABE, M.; KOTHARI, T. Emerging market multinational companies' evolutionary paths to building a competitive advantage from emerging markets to developed countries. Journal of World Business, Greenwich, v. 51, n. 5, p. 729-743, 2016. DOI: 10.1016/j.jwb.2016.07.010.

KUBO, E. K. M.; BRAGA, B. M. Ajustamento intercultural de executivos japoneses expatriados no Brasil: um estudo empírico. Revista de Administração de Empresas, São Paulo, v. 53, n. 3, p. 243-255, 2013. DOI: 10.1590/S0034-75902013000300003.

LIEBERMAN, M. B.; MONTGOMERY, D. B. First-movers advantages. Strategic Management Journal, Hoboken, v. 9, n. 5, p. 41-58, 1988. DOI: 10.1002/smj.4250090706.

LIMA, M. B.; BRAGA, B. A. Práticas de recursos humanos do processo de repatriação de executivos brasileiros. Revista de Administração Contemporânea, Curitiba, v. 14, n. 6, p. 1031-1053, 2010. DOI: 10.1590/S1415-65552010000700004.

MASON, J. (2010). Qualitative researching. London: SAGE Publications, 2010.

MENDENHALL, M. E.; DUNBAR, E.; ODDOU, G. R. Expatriate selection, training and careerpathing: a review and critique. Human Resource Management, Hoboken, v. 26, n. 3, p. 331345, 1987. DOI: 10.1002/hrm.3930260303.

ORSI, A.; BERTOIA, N.; BARBOSA-LIMA, M. Gestão internacional de recursos humanos. São Paulo: Elsevier, 2015.

REGO, A.; CUNHA, M. P. Manual de gestão transcultural de recursos humanos. Lisboa: RH Editora, 2009.

REYNOLDS, C. Expatriate compensation in historical perspective. Journal of World Business, Greenwich, v. 32, n. 2, p. 118-132, 1997. DOI: 10.1016/S1090-9516(97)90003-1.

ROCHA, T. V.; BORINI, F. M. Mecanismos de transferência de conhecimento: uma comparação entre multinacionais tradicionais e emergentes. Revista de Administração e Inovação, São Paulo, v. 8, n. 2, 240-265, 2011. DOI: 10.5773/rai.v8i2.563. 
SHEN, K. N.; XIE, X. Moving from the developing to the developed: compensation disparities of Chinese expatriates. Asia Pacific Journal of Human Resources, Melbourne, v. 56, n. 2, p. 260-285, 2018. DOI: 10.1111/1744-7941.12113.

SHI, X.; FRANKLIN, P. Business expatriates' cross-cultural adaptation and their job performance. Asia Pacific Journal of Human Resources, Melbourne, v. 52, n. 2, p. 193-214, 2014. DOI: 10.1111/1744-7941.12003.

SUUTARI, V.; BREWSTER, C. Repatriation: empirical evidence from a longitudinal study of career sand expectations among Finnish expatriates. International Journal of Human Resource Management, London, v. 14, n. 7, p. 1132-1151, 2003. DOI: 10.1080/0958519032000114200.

TANURE, B.; CYRINO, A. B.; PENIDO, E. Estratégias de internacionalização: evidências e reflexões sobre empresas brasileiras. In: FLEURY, A.; FLEURY, M. T. L. (Orgs.).

Internacionalização e os países emergentes. São Paulo: Atlas, 2007. p. 198-213.

THITE, M. International human resource management in multinational corporations from emerging markets. In: HORWITZ, F.; BUDHWAR, P. (Eds.). Handbook of Human Resource Management in Emerging Markets. Cheltenham: Edward Elgar Publishing Limited, 2015. p. 97-121.

TUNG, R. L. Selection and training procedures of U.S., European, and Japanese multinationals. California Management Review, Berkeley, v. 25, n. 1, p. 57-71, 1982. DOI: $10.2307 / 41164993$.

VIANNA, N. P.; SOUZA, Y. S. Uma análise sobre os processos de expatriação e repatriação em organizações brasileiras. Revista de Administração e Contabilidade da Unisinos, São Leopoldo, v. 6, n. 4, p. 340-353, 2009. DOI: 10.4013/base.2009.64.05.

WENTLAND, D. M. A new practical guide for determining expatriate compensation: the comprehensive model. Compensation and Benefits Review, New York, v. 35, n. 3, 45-50, 2003. DOI: $10.1177 / 0886368703035003006$.

YAHIAOU, D. Hybridization: striking a balance between adoption and adaptation of human resource management practices in French multinational corporations and their Tunisian subsidiaries. The International Journal of Human Resource Management, London, v. 26, n. 13, p. 1665-1693, 2004. DOI: 10.1080/09585192.2014.958513.

YIN, R. K. Estudo de caso. Porto Alegre: Bookman, 2010.

ZHANG, M. M.; FAN, D. Expatriate skills training strategies of Chinese multinationals operating in Australia. Asia Pacific Journal of Human Resources, Melbourne, v. 52, n. 1, p. 60-76, 2014. DOI: 10.1111/1744-7941.12023.

ZWIELEWSKI, G.; TOLDO, S. Qualidade de vida no trabalho de profissionais expatriados para Índia e China. Revista Eletrônica de Administração, Porto Alegre, v. 2, n. 1, p. 510-542, 2016. DOI: 10.1590/1413-2311.0462015.53604. 